\title{
Growth Performance and Nutrient Composition of Mustard Green (Brassica juncea) cultured in Aquaponics Systems and Hydroponic System
}

\author{
Prayogo $^{1}$, Agustono ${ }^{1}$, Boedi Setya Rahardja ${ }^{1}$ and Muhamad Amin ${ }^{1^{*}}$ \\ ${ }^{1}$ Department of Aquaculture, Faculty of Fisheries and Marine, Universitas Airlangga, Jl. Mulyorejo, \\ Mulyorejo, Surabaya 60115, Indonesia
}

*Correspondence :

muhamad.amin@fpk.unair.ac.id

Received : 2021-04-29

Accepted : 2021-08-02

Keywords :

Aquaponic, Growth, Hydroponics mustard green, Nutrient content

\begin{abstract}
Aquaculture waste is rich in various nutrient contents from uneaten feed, feces, or urine including nitrogen in terms of total ammonium nitrogen (TAN) and nitrite. With the help of nitrifying bacteria, the nitrogen wastes can be converted into nitrate which is one of the main components of commercial fertilizer in agriculture. This study aimed at comparing the growth and nutrient contents (crude protein, crude fat, energy, and antioxidant) of mustard Green (Brassica juncea) cultured in different culture media (aquaculture waste which is generally known as the aquaponics system vs hydroponic system which used commercial inorganic fertilizer). The aquaponics system was prepared by previously growing Nile tilapia fingerling, Oreochromis niloticus, for $\sim 2$ weeks to reach nitrate concentration on the effluent water $\sim 30 \mathrm{mg} / \mathrm{L}$. Mustard Green was cultured in the system for 30 days. Nutrient availability in both systems was also monitored by measuring nitrate content and total dissolved solids. The results showed that the growth, nutrient content including crude protein, crude fat, total energy, and antioxidant content of the vegetable were not significantly different between the system, $p>0.05$. Nutrient availability especially in terms of nitrate was also not significantly different between the culture system. These results suggest that the aquaponics system could be used to produce vegetables with the same growth and nutrient content as a vegetable grown in the aquaponics system. Furthermore, aquaculture waste can be used to replace inorganic fertilizer to grow vegetables which later contribute to the reduction of total production cost.
\end{abstract}

\section{INTRODUCTION}

Total feed which could be deposited into meat is about $28 \%$ of the total feed given, and the rest is accumulating in terms of organic matter or dissolved in the water column. As reported by Amin et al. (2020), out of the total feed given, fish took up less than $28 \%$ of nitrogen and $29 \%$ of phosphorus fish flesh. While the majority of the nutrient content in the feed was ended up as aquaculture waste, $17 \%$ of feed nitrogen and 52\% of feed phosphorus become feces, and $10 \%$ of the feed nitrogen and $44 \%$ of the phosphorus feed in sediments. When the rearing water is discharged into the environment, the nutrient may go along with it and may 
cause pollution. This issue has been raised in several aquaculture farms especially those fish farms which still use conventional or open aquaculture systems. As the result, aquaculture industries have been blamed for eutrophication and the silting of natural ponds and reservoirs (Amir et al., 2018). As the consequence, various studies have been developed to address this issue and to have an ecofriendly aquaculture system.

One of the most common ecofriendly aquaculture systems being practiced in Indonesia, sis called an aquaponic system. The system, in general, combines two culture systems which are the aquaculture system in which fish are cultured and the hydroponics system in which vegetables are grown (Lennard and Goddek, 2019). Instead of discharging effluent water of aquaculture wastes containing feces, uneaten feed, and urine which are still rich in nutrients, it is used to grow vegetables (Paudel, 2020; Rakocy, 2012). The main principle of the aquaponic system is to utilize aquaculture waste especially nitrate $\left(\mathrm{NO}_{3}\right)$ from the degradation of feces, uneaten feed which is still rich in nutrient content to grow vegetable biomass (Yep and Zheng, 2019). In addition, the ability to convert waste into vegetable biomass also allows reusing of rearing water and lead to use significantly less water than open aquaculture system. Due to these advantages, several authors stated that the aquaponic system, not only have been considered as an eco-friendly aquaculture system but also requires less operational cost and have more benefit than other conventional or open aquaculture system (Asciuto et al., 2019; Yep and Zheng, 2019).

However, some researchers have questioned the growth and quality of nutrient contents of vegetables produced in the aquaponic system. Several authors argue that several nutrient contents are unavailable in the aquaculture waste, thus the nutrient content of the vegetable are lower than those vegetables produced in hydroponic using inorganic fertilizer
(Goddek et al., 2015). Nonetheless, other authors stated that nutrient required by vegetables to grow has been already available in the aquaculture waste including nitrogen in the form of nitrate and also phosphor in terms of phosphate $\left(\mathrm{PO}_{4}\right)$ (Eck et al., 2019). The differences therefore should be further investigated to get a clearer overview of nutrient availability from aquaculture waste. Acknowledging this information, this study aimed at investigating the growth and nutrient composition of vegetables produced from aquaponics systems using effluent of aquaculture. The study result is expected to give a general overview of the growth and nutrient content of vegetables grown in aquaculture waste or using commercial inorganic fertilizer.

\section{METHODOLOGY}

\section{Place and Time}

This research was conducted for 1 month from 22 August to 23 September 2020. The experimental work such as cultured vegetables in the aquaponics or hydroponic was performed at the experimental field station at Mataram, West-Nusa Tenggara. While, data analysis including proximate analysis was performed at Laboratory of Chemistry, University Mataram, West Nusa Tenggara Province, Indonesia.

\section{Research Materials}

This study used several materials including nitrate test kits (HANNA HI 96786 Nitrate Portable Photometer, three sets of an aquaponics system, three units of hydroponic systems, total dissolved meter (TDS and EC Meter), a ruler, and digital balance.

\section{Research Design}

The experiment used three aquaponic systems in which vegetable was grown using effluent water, and three systems in which vegetable was grown using commercial inorganic fertilizers. The hydroponic systems were prepared according to a protocol of Jones Jr (2016), 
while aquaponic systems were prepared according to a protocol previously described by Rakocy (2012). Before the experiment was started, the nitrate content of culture water was adjusted to be the same to provide the nutrient for the growing vegetables.

\section{Work Procedure}

\section{Preparation of Aquaponics System}

The present study used three aquaponic units, and each of which consisted of a $25 \mathrm{~L}$ rearing tank, $20 \mathrm{~L}$ waste treatment tank, and four PVC for a hydroponic system. The rearing tank was filled with well water. Each rearing tank was stocked with 24 Nile tilapia with an average weight of $1.12 \pm 0.1 \mathrm{~g}$ and fed four times daily (8 a.m., 11 a.m., 2 p.m., and 5 p.m.) at satiation level for $5 \mathrm{~min}$ with a commercial diet containing 41\% crude protein. Nitrate and total dissolved solids (TDS) were measured daily. When nitrate concentration reached $30 \mathrm{mg} / \mathrm{L}$ and TDS from 900-1200 mg/L, 7day mustard green was added to the system.
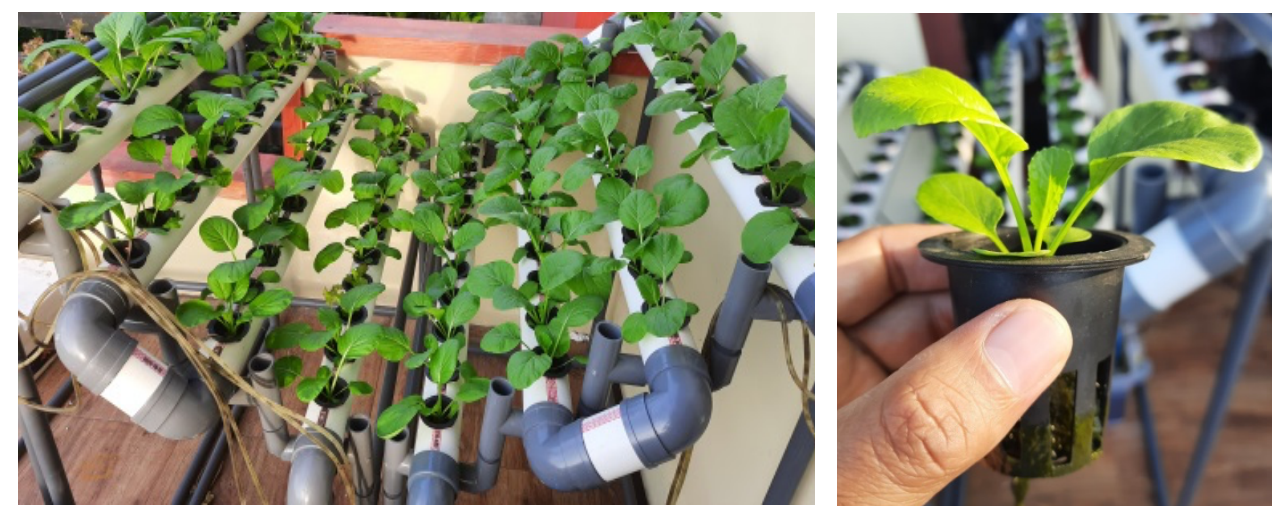

Figure 1. Mustard green (Brassica juncea) cultured in aquaponics and hydroponics systems.

\section{Hydroponics System}

While hydroponic system consisted of a sum tank of 25L rearing tanks (the same volume as the rearing unit of the aquaponic system. Then, commercial inorganic fertilizer (ABmix) was diluted as the manufacture protocol, and nitrate concentration was measured at about 30 $\mathrm{mg} / \mathrm{L}$ and total suspended solids (TDS) of 900-1,000 mg/L. The AB mix fertilizer consisted of several elements including $204,3 \mathrm{gr} / \mathrm{kg} 5 \mathrm{Ca}\left(\mathrm{NO}_{3}\right) 2 \cdot \mathrm{NH}_{4} \mathrm{NO}_{3} \cdot 10 \mathrm{H}_{2} \mathrm{O}$, $21,5 \mathrm{gr} / \mathrm{kg} \mathrm{KNO}_{3}, 4.75 \mathrm{gr} / \mathrm{kg} \mathrm{C}_{10} \mathrm{H}_{12} \mathrm{~N}_{2} \mathrm{O}_{8}$ FeNa. $3 \mathrm{H}_{2} \mathrm{O}, 2,47 \mathrm{gr} / \mathrm{kg} \mathrm{C}{ }_{18} \mathrm{H}_{16} \mathrm{~N}_{2} \mathrm{O}_{6} \mathrm{FeNa}$,

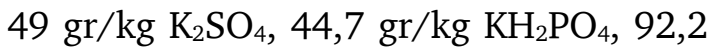
$\mathrm{gr} / \mathrm{kg} \mathrm{MgSO}{ }_{4} .7 \mathrm{H}_{2} \mathrm{O}, 8,4 \mathrm{gr} / \mathrm{kg}\left(\mathrm{NH}_{4}\right) 2 \mathrm{SO}_{4}$, 0,573 gr/ $/ \mathrm{kg} \mathrm{H}_{3} \mathrm{BO}_{3}, 0,134 \mathrm{gr} / \mathrm{kg}$ ZnEDTA, $0,770 \mathrm{gr} / \mathrm{kg}$ MnEDTA, 0,143 $\mathrm{gr} / \mathrm{kg}$ CuEDTA, and 0,025 gr/ $/ \mathrm{kg} \mathrm{Na}_{2} \mathrm{MoO}_{4} \cdot 2 \mathrm{H}_{2} \mathrm{O}$ (Zamriyetti et al., 2019). Then 7-day mustard green (Brassica juncea) was added to the system and cultured for 30 days. Reduction of water due to evaporation was replaced with well water.

\section{Water Quality}

Nitrate concentration was measured with HANNA HI 96786 Nitrate Portable Photometer and total dissolved solids were analyzed twice a week to monitor nutrient concentration in both aquaponic and hydroponic systems.

\section{Measured Variables}

The absolute growth of the vegetables was measured by weighing the initial weight and final weight of the mustard green. In addition, total biomass was also calculated at the and of the experimental periods. Growth and total biomass harvested from each tank were calculated using the following formula:

$\mathrm{WG}=\mathrm{Wt}-\mathrm{Wo}$ 
Where:

WG = weight gain $(\mathrm{g})$

$\mathrm{Wt} \quad=$ final weight $(\mathrm{g})$

Wo = initial weight $(\mathrm{g})$

Biomass $(\mathrm{g} /$ tank $)=$ total biomass harvested per tank

Proximate analysis (water content, crude protein, crude fat, the energy content in vegetables harvested from each culture system) was determined. In brief, crude protein was measured using Kjeldahl analysis, fat content used socket, and energy content using a bomb calorimeter. While antioxidant content was measured according to a protocol previously described by Miller et al. (2000).

\section{Data Analysis}

Data of initial weight, final weight, weight gain, crude protein, crude fat, crude energy, and antioxidant content were presented as mean value \pm standard deviation. Then, these values were compared using analysis of independent $\mathrm{t}$ test, at $p<0.05$ using SPSS software version 22 . The same method was also used to compare nutrient content parameters including nitrate and total dissolved solids between culture systems.

\section{RESULTS AND DISCUSSION}

Nitrate is an important fertilizer component for growing vegetables. Among the most common commercial form of nitrate is potassium nitrate $\left(\mathrm{KNO}_{3}\right)$ (Çalişkan and Çalişkan, 2019). On the other hand, nitrate content which is the main result of aquaculture wastes degradation by nitrifying bacteria has been considered pollution, therefore, should be taken out from the fish rearing system through water exchange (Gao et al., 2020). The present study reported the growth and nutrient composition of mustard green cultured in effluent water of Nile tilapia aquaculture (generally known as an aquaponics system). To compare with, mustard greens were also cultured in a hydroponic system and used a commercial inorganic fertilizer as nutrient supply.

The result, in general, showed that the growth and nutrient composition of mustard green culture using effluent water of tilapia culture were not significantly different from that of mustard green harvested from the hydroponic system.

\section{Growth and Total Harvested Biomass}

Started from the same initial weight of biomass $(p>0.05)$ with an average of $\sim 3 g$ (Table 1), the average weight of mustard green harvested from the aquaponic system after the 30 culture period was statistically no significant difference from the vegetable harvested from hydroponic, $p>0.05$. As presented in Table 1, the mustard green cultured in the aquaponic system and the hydroponic systems had statistically similar growth. Similar results have been previously confirmed by Lennard and Ward (2019) in which the growth rate of three types of vegetables: Lettuce (Lactuca sativa L.), dill (Anethum graveolens L.), rocket (Eruca sativa), coriander (Coriandrum sativum L.), and parsley (Petroselinum crispum) cultured in aquaponics system had the same growth as that of cultured in a hydroponics system.

The same result had been also reported by Jordan et al. (2018), where the growth and yield of Lettuce cultured in an aquaponics system were not significantly different from that lettuce grown in a hydroponic system. Bittsanszky et al. (2016) added that green leafy such as mustard green thrive well although some micronutrient concentration in the aquaponic system is slightly lower. The result may suggest that nutrients required by the vegetables were also available and can fulfill the vegetable requirement to grow as good as a commercial fertilizer in hydroponic systems. 
Table 1. The performance index of mustard green cultured in the aquaponics system and hydroponics system for 30 days.

\begin{tabular}{lcc}
\hline \multirow{2}{*}{\multicolumn{1}{c}{ Performances }} & \multicolumn{2}{c}{ Average \pm St dev } \\
\cline { 2 - 3 } & Aquaponics & Hydroponics \\
\hline Initial Weight $(\mathrm{g})$ & $3.06 \pm 0.42^{\mathrm{a}}$ & $3.14 \pm 0.57^{\mathrm{a}}$ \\
Final Weight $(\mathrm{g})$ & $37.38 \pm 25.23^{\mathrm{A}}$ & $43.38 \pm 32.65^{\mathrm{A}}$ \\
Weight gain $(\mathrm{g})$ & $33.02 \pm 0.76^{\mathrm{x}}$ & $39.21 \pm 0.50^{\mathrm{x}}$ \\
Total harvested Biomass $(\mathrm{g})$ & $1,794.14 \pm 224.70^{\mathrm{b}}$ & $2,082.16 \pm 142.92^{\mathrm{b}}$ \\
\hline
\end{tabular}

Note: values are average with a standard deviation of three-unit replicates. Different superscripts within a row indicate significantly different at $\mathrm{p}<0.05$.

\section{Proximate Composition of Mustard Green}

The proximate compositions of mustard green harvested from the Aquaponics and hydroponic system were presented in Table 2. The result, in general, showed that there were no significant differences in all measured parameters including water content, crude protein, crude fat, ash, antioxidant and energy content. Water content of mustard green ranged from $91-97 \%(t=1.74$, df $10,9, \mathrm{t}=0.11$ ). While crude protein was quite high which was $26-30 \%(\mathrm{t}=1.50$, df
$4,2, t=0.24)$. Similarly, other parameters including Crude fat, antioxidant, and energy content of mustard green harvested from the two different systems. This result was in agreement with a study by Delgadillo-Díaz et al. (2019) stating that plant quality including antioxidant, flavonoid and carotenoids contents cultured in the aquaponic system was very similar to another growing system. All these results suggest that vegetables grown using effluent of aquaculture waste had the same nutrient quality as vegetables cultured using the commercial inorganic fertilizers.

Table 2. Proximate composition and antioxidant content of mustard green cultured in either aquaponics system or hydroponics system for 30 days.

\begin{tabular}{lcc}
\hline \multirow{2}{*}{ Performance Index } & \multicolumn{2}{c}{ Average \pm Stdev } \\
\cline { 2 - 3 } & Aquaponics & Hydroponics \\
\hline Water content (\%) & $97.70 \pm 0.91^{\mathrm{a}}$ & $91.68 \pm 0.16^{\mathrm{a}}$ \\
Crude Protein (\%) & $30.22 \pm 3.22^{\mathrm{a}}$ & $26.15 \pm 2.85^{\mathrm{a}}$ \\
Crude Fat (\%) & $0.40 \pm 0.13^{\mathrm{a}}$ & $0.37 \pm 0.18^{\mathrm{a}}$ \\
Energy (Joule/g) & $3,227.00 \pm 409.26^{\mathrm{a}}$ & $2,952.00 \pm 208.60^{\mathrm{a}}$ \\
Antioksidan (\%) & $70.78 \pm 4.36^{\mathrm{a}}$ & $79.81 \pm 8.41^{\mathrm{a}}$ \\
Ash (\%) & $1.40 \pm 0.19^{\mathrm{a}}$ & $1.56 \pm 0.32^{\mathrm{a}}$ \\
\hline
\end{tabular}

Note: Values are the average and standard deviation of triplicates. The same superscript indicates there were not significantly different ( $p>0.05)$.

\section{Nutrient Availability}

Two parameters of nutrient availability in the aquaponics or hydroponics system including nitrate and total dissolved solids (TDS) were presented in Table 3. Average values of nitrate in both culture systems were not significantly different, all $p>0.05$. the same results were obtained from TDS concentration which was about 98-110 $\mathrm{mg} / \mathrm{L}, \mathrm{p}>0.05$. These parameters were frequently used as an indicator of nutrient availability in aquaponics and hydroponics system. Roosta and Hamidpour (2011) reported that total dissolved solids concentration in water of hydroponic system should be more than $300 \mathrm{mg} / \mathrm{L}$. While total dissolved solid concentrations obtained in this present study were much higher in both systems, which suggests that nutrient availability is at the optimum level for growing vegetables. 
Table 3. Nitrate and total dissolved solids (TDS) were measured in the culture media of the aquaponic system and hydroponic system.

\begin{tabular}{ccc}
\hline \multirow{2}{*}{ Parameters } & \multicolumn{2}{c}{ Average \pm Stdev } \\
\cline { 2 - 3 } & Aquaponics & Hydroponics \\
\hline Nitrate & $32 \pm 1.25^{\mathrm{N}}$ & $30 \pm 0.06^{\mathrm{M}}$ \\
TDS & $1001 \pm 83.29^{\mathrm{p}}$ & $973.33 \pm 152.75^{\mathrm{p}}$ \\
\hline
\end{tabular}

Note: Values are the average and standard deviation of triplicates. Values with the different superscripts in the same row indicated that there was a significant difference at $\mathrm{p}<0.05$.

\section{CONCLUSION}

Mustard green (Brassica juncea) cultured in an aquaponics system showed similar growth and nutrient composition as that mustard green cultured in the hydroponic system with commercial inorganic fertilizer. This result suggests that an aquaponics system is a potential method to grow vegetables, because not only producing more biomass but is also a very eco-friendly aquaculture system. In addition, the use of aquaculture waste is a potential way to replace inorganic fertilizer to grow vegetables because can reduce the significantly total production cost, especially for commercial fertilizer.

\section{ACKNOWLEDGMENT}

The authors thank all colleges in the laboratory of fish Nutrition, the Faculty of Fisheries, and Marine Universitas Airlangga for providing help, advice, and facilities during data curation, data analysis, and preparing the manuscript. This study was funded by Universitas Airlangga under scheme "Riset Kolaborasi Luar Negeri" with contract number 408/UN3.14/PT/2020.

\section{REFERENCES}

Amin, M., Musdalifah, L. and Ali, M., 2020. Growth performances of Nile Tilapia, Oreochromis niloticus, reared in recirculating aquaculture and active suspension systems. IOP Conference Series: Earth and Environmental Science, 441, 012135. https://doi.org/10.1088/17551315/441/1/012135

Amir, S., Setyono, B.D.H., Alim, S. and Amin, M., 2018. Aplikasi teknologi bioflok pada budidaya udang vaname (Litopenaeus Vannamei). Prosiding Konferensi Nasional Pengabdian Kepada Masyarakat dan Corporate Social Responsibility (PKM-CSR), 1, pp.660-666. https:// prosiding-pkmcsr.org/index.php/pk mcsr/article/view/245/82

Asciuto, A., Schimmenti, E., Cottone, C. and Borsellino, V., 2019. A financial feasibility study of an aquaponic system in a Mediterranean urban context. Urban Forestry \& Urban Greening, 38, pp.397-402. https://d oi.org/10.1016/j.ufug.2019.02.001

Bittsanszky, A., Uzinger, N., Gyulai, G., Mathis, A., Junge, R., Villarroel, M., Kotzen, B. and Kömíves, T., 2016. Nutrient supply of plants in aquaponic systems. Ecocycles, 2(2), pp.17-20. http://dx.doi.org/10.190 40/ecocycles.v2i2.57

Çalişkan, B. and Çalişkan, A.C., 2019. Potassium nutrition in plants and its interactions with other nutrients in hydroponic culture. In Improvement of Quality in Fruits and Vegetables Through Hydroponic Nutrient Management, IntechOpen, London, pp.9-22.

Delgadillo-Díaz, M., Gullian-Klanian, M., Sosa-Moguel, O., Sauri-Duch, E. and Cuevas-Glory, L.F., 2019. Evaluation of physico-chemical characteristics, antioxidant compounds and antioxidant capacity in creole tomatoes (Solanum lycopersicum L. and $S$. pimpinellifolium L.) in an aquaponic system or organic soil. International Journal of Vegetable Science, 25(2), pp.124-137. https:// doi.org/10.1080/19315260.2018.1 487496 
Eck, M., Körner, O. and Jijakli, M.H., 2019. Nutrient cycling in aquaponics systems. In: Goddek S., Joyce A., Kotzen B., Burnell G.M. (eds) Aquaponics Food Production Systems. Springer, Cham. https://do i.org/10.1007/978-3-030-15943-6 9

Gao, Y., Guo, L., Shao, M., Hu, F., Wang, G., Zhao, Y., Gao, M., Jin, C. and She, Z., 2020. Heterotrophic denitrification strategy for marine recirculating aquaculture wastewater treatment using mariculture solid wastes fermentation liquid as carbon source: Optimization of COD/NO3--N ratio and hydraulic retention time. Bioresource technology, 304, 122982. https://doi.org/10.1016/j.biortech. 2020.122982

Goddek, S., Delaide, B., Mankasingh, U., Ragnarsdottir, K. V., Jijakli, H. and Thorarinsdottir, R., 2015. Challenges of sustainable and commercial aquaponics. Sustainability, 7(4), pp.4199-4224. https://doi.org/10.3390/su704419 9

Jones Jr, J.B., 2016. Hydroponics: a practical guide for the soilless grower. CRC press.

Jordan, R.A., Ribeiro, E.F., de Oliveira, F.C., Geisenhoff, L.O. and Martins, E.A., 2018. Yield of lettuce grown in hydroponic and aquaponic systems using different substrates. Revista Brasileira de Engenharia Agrícola e Ambiental, 22(8), pp.525-529. http: //dx.doi.org/10.1590/1807-1929/a griambi.v22n8p525-529

Lennard, W. and Goddek, S., 2019. Aquaponics: the basics. In: Goddek S., Joyce A., Kotzen B., Burnell G.M. (eds) Aquaponics Food Production Systems. Springer, Cham. pp.113143. https://doi.org/10.1007/9783-030-15943-6_5

Lennard, W. and Ward, J., 2019. A comparison of plant growth rates between an NFT hydroponic system and an NFT aquaponic System. Horticulturae, 5(2), p.27. https://doi.org/10.3390/horticultu rae5020027

Miller, H.E., Rigelhof, F., Marquart, L., Prakash, A. and Kanter, M., 2000. Antioxidant content of whole grain breakfast cereals, fruits and vegetables. Journal of the American College of Nutrition, 19(sup3), pp.312S-319S. https://doi.org/10.1 080/07315724.2000.10718966

Paudel, S.R., 2020. Nitrogen transformation in engineered aquaponics with water celery (Oenanthe javanica) and koi carp (Cyprinus carpio): Effects of plant to fish biomass ratio. Aquaculture, 520, 734971. https://doi.org/10.1016/j. aquaculture.2020.734971

Rakocy, J.E., 2012. Aquaponics: integrating fish and plant culture. Aquaculture production systems, 1, pp.343-386. https://doi.org/10.100 2/9781118250105.ch14

Roosta, H.R. and Hamidpour, M., 2011. Effects of foliar application of some macro- and micro-nutrients on tomato plants in aquaponic and hydroponic systems. Scientia Horticulturae, 129(3), pp.396-402. http://dx.doi.org/10.1016/j.scienta .2011.04.006

Yep, B. and Zheng, Y., 2019. Aquaponic trends and challenges - A review. Journal of Cleaner Production, 228, pp.1586-1599. https://doi.org/10.1 016/j.jclepro.2019.04.290

Zamriyetti, Siregar, M. and Refnizuida, 2019. Pertumbuhan dan produksi tanaman sawi (Brassica juncea L.) dengan aplikasi beberapa konsentrasi nutrisi $\mathrm{AB}$ Mix dan monosodium glutamat pada sistem tanam hidroponik Wick. Agrium: Jurnal Ilmu Pertanian, 22(1), pp. 5661. http://dx.doi.org/10.30596\%2Fagr ium.v22i1.3105 